\title{
Produksi karkas, nilai gizi dan profil asam lemak daging serta produksi limbah kelinci New Zealand White akibat penyertaan rumput laut cokelat (Sargassum sp.) pada ransum
}

\author{
Sutaryo *, Alief Jannah, Auliya Rizqi, Dian Lestari, Agung Purnomoadi \\ Departemen Peternakan, Fakultas Peternakan dan Pertanian Universitas Diponegoro, Tembalang, Semarang, \\ 50275 \\ *Correspondence: soeta@lecturer.undip.ac.id
}

Received: November $3^{\text {th }}, 2020$; Accepted: February 15 ${ }^{\text {th }}, 2021$; Published online: March $22^{\text {th }}, 2021$

Abstrak

Tujuan: Penelitian ini bertujuan untuk mengevaluasi pernyertaan Sargassum sp. pada pakan terhadap kandungan nutrien, profil asam lemak daging dan produksi limbah kelinci New Zealand White (NZW).

Metode: Dua puluh empat kelinci NZW umur 70-80 hari dengan rerata bobot badan $1736 \pm 50 \mathrm{~g}$ dibagi secara acak ke dalam tiga perlakuan. Perlakuan yang diterapkan: (T1) kelinci diberi pakan basal, T2: penyertaan 4\% Sargassum sp. pada pakan basal dan T3: penyertaan 8\% Sargassum sp. pakan basal.

Hasil: Hasil penelitian menunjukkan bahwa perlakuan penyertaan Sargassum sp. pada ransum tidak berpengaruh nyata $(\mathrm{P}>0,05)$ terhadap kadar air, kadar abu, kadar protein otot Longisimus dorsi, persentase karkas, bobot karkas panas, bobot karkas dingin, produksi limbah padat dan limbah cair. Namun demikian perlakuan penyertaan Sargassum sp. pada ransum berpengaruh nyata $(\mathrm{P}<0,05)$ dapat menurunkan kadar lemak otot LD kelinci NZW. Penggunaan Sargassum sp. juga tidak berpengaruh banyak terhadap profil asam lemak otot LD kelinci NZW.

Kesimpulan: Penggunaan Sargassum sp. pada ransum kelinci sampai pada taraf $8 \%$ tidak berdampak pada produksi karkas, kandungan protein, abu dan air daging, serta produksi limbah yang dihasilkan. Bahkan penyertaan Sargassum sp. pada ransum pada taraf $4 \%$ mampu menurunkan kandungan lemak daging kelinci. Dengan demikian ditinjau dari parameter pengamatan di atas Sargassum sp. dapat digunakan untuk mensubstitusi bahan pakan kelinci sampai dengan taraf $8 \%$.

Kata Kunci: Kandungan nutrien; Kelinci; Asam lemak; Produksi limbah

Abstract

Objective: The aim of this current paper was to evaluate effect of inclusion Sargassum sp. in the ration on meat nutrient content, meat fatty acid profile and waste production of New Zealand White (NZW) rabbit.

Methods: Twenty four NZW rabbit (70-80 d old) with initial body weight $1736 \pm 50$ g were randomly allocated in to three treatments. The treatments were: T1 basal feed, T2 inclusion of $4 \%$ Sargassum sp. in the basal feed and T3 inclusion of 8\% Sargassum sp. in the basal feed. 
Results: Results of this experiment showed that inclusion of Sargassum sp. in the ration gave no effect $(\mathrm{P}>0.05)$ on the moisture, ash, crude protein content of Longisimus dorsi (LD) muscle, carcass percentage, warm carcass weight, cold carcass weight and waste production. However, the treatment was significantly $(\mathrm{P}<0.05)$ decreasing fat content of LD muscle. Fatty acids profile of all treatments was relatively same.

Conclusions: Utilization of Sargassum sp. in the rabbit ration up to $8 \%$ has no impact on the carcass production, protein, ash, and meat water content, and the waste production. Even the inclusion of Sargassum sp. the ration at level of $4 \%$ can reduce the fat content of rabbit meat. Thus, based on the observed parameters Sargassum sp. can be used to substitute rabbit feed up to a level of $8 \%$.

Keywords: Meat nutrient; Rabbit; Fatty acids profile; Waste production

\section{PENDAHULUAN}

Peningkatan taraf hidup suatu bangsa seringkali akan diikuti dengan pergeseran pola makan dari konsumsi dominan pangan sumber karbohidrat ke pangan sumber protein. Kenyataan ini merupakan salah satu penyebab kenaikan permintaan sumber protein hewani tak terkecuali di Indonesia.

Diantara ternak yang potensial untuk dikembangkan sebagai sumber protein hewani adalah ternak kelinci. Keistimewaan ternak ini untuk produksi daging diantaranya adalah periode regenerasi yang pendek, periode kebuntingan yang singkat, pertumbuhan yang cepat, pemasaran ternak pada usia muda dan kebutuhan luasan kandang yang relatif lebih sempit dibanding ternak yang lainnya [1], biaya produksi yang relatif rendah dan efisien dalam mengkoversi hijauan menjadi daging [2]. Selain beberapa keunggulan diatas, produk utama dari budidaya ternak kelinci yang berupa daging juga mempunyai beberapa kelebihan dibandingkan dengan daging dari ternak sapi dan kambing misalnya. Hal ini terlihat dari kandungan proteinnya yang tinggi (20-21\%) dengan kandungan asam amino essensial yang mempunyai tingkat kecernaan yang tinggi, kandungan lemak yang rendah dengan sedikit asam lemak jenuh dan kandungan kolesterol yang rendah. Dengan berbagai keunggulan tersebut daging kelinci dikenal sebagai pangan bergizi tinggi dan menyehatkan [3].

Keberhasilan usaha peternakan salah satunya ditentukan oleh kualitas dan kuantitas pakan yang dikonsumsi ternak. Untuk dapat memenuhi kebutuhan nutrien pada ternak dapat disuplai baik melalui pemberian hijauan maupun konsentrat. Namun demikian untuk keperluan tersebut seringkali peternak terkendala oleh mahalnya harga pakan konvensional yang mahal [4]. Upaya yang dapat ditempuh adalah dengan mencari sumber pakan yang alternatif yang tidak bersaing peruntukkannya untuk pangan manusia, harganya relatif murah namun nilai nutrisinya tetap dapat memenuhi kebutuhan ternak.

Diantara sumber pakan ternak alternatif yang memenuhi kriteria tersebut diantaranya adalah rumput laut Sargassum sp. Kandungan nutrisi rumput laut coklat ini adalah karbohidrat sebesar $65,48 \%$, neutral detergen fibre sebesar $75,45 \%$ dan protein kasar sebesar 6,98 \% [5]. Rumput laut jenis ini dapat tumbuh subur tanpa harus dibudidayakan secara khusus baik didaerah tropis maupun sub-tropis terutama di pantai berbatu dan berkerikil [6]. Evaluasi Sargassum sp. sebagai pakan ternak pernah dilakukan oleh Marín et al. [7] yang dalam studinya mengevaluasi penggunaan Sargassum sp. sebagai pakan ternak domba pada level $0,10,20$ dan $30 \%$ terhadap kecernaan bahan kering, $\mathrm{pH}$, ammonia dan produksi volatile fatty acid (VFA) cairan rumen. Hasil penelitian menunjukkan bahwa kecernaan bahan kering (BK) berkisar antara 74\%-79\%. Perlakuan penggunaan rumput laut coklat secara nyata $(\mathrm{P}<0,05)$ menaikkan $\mathrm{pH}$ rumen, menurunkan konsentrasi VFA rumen dan tidak berpengaruh nyata $(\mathrm{P}>0,05)$ terhadap konsentrasi ammonia. Hambakodu et al. [5] mengevaluasi substitusi rumput gajah dengan rumput laut coklat (Sargassum polycystum) terhadap produk metabolisme rumen dan kecernaan nutrien secara in vitro dengan hasil bahwa substitusi rumput 
gajah dengan rumput laut coklat tidak berpengaruh nyata $(\mathrm{P}>0,05)$ pada nilai $\mathrm{pH}$, konsentrasi N-NH3, VFA total, asetat, propionat, butirat, adenosin trifosfat (ATP), kecernaan bahan kering, kecernaan bahan organik, dan kecernaan neutral detergent fiber (NDF). Sementara itu hasil penelitian Matanjun et al. [8] menemukan bahwa konsentrasi asam lemak palmitat pada Sargassum polycystum mencapai 37,97\% jauh lebih tinggi dibanding kandungan asam lemak palmitat pada rumput laut Eucheuma cottonii $(15,10 \%)$ dan Caulerpa lentillifera $(33,78 \%)$. Berawal dari hasil penelitian tersebut diatas dirasa perlu untuk dilakukan penelitian mengenai pemanfaatan rumput laut coklat (Sargassum sp.) sebagai bagian ransum kelinci terhadap produksi karkas, nilai gizi dan profil asam lemak daging serta produksi limbah kelinci. Penelitian ini bertujuan untuk mengkaji substitusi sebagian pakan dengan Sargassum sp. terhadap kandungan nutrien dan profil asam lemak daging dan produksi limbah kelinci. Disamping kandungan nutrien daging, informasi mengenai produksi limbah kelinci sangat diperlukan terutama sebagai sumber informasi dalam perencanaan budidaya ternak kelinci pada skala industri.

\section{MATERI DAN METODE}

\section{Ternak Kelinci dan Ransum}

Kelinci yang digunakan dalam penelitian ini adalah kelinci bangsa New Zealand White (NZW) dengan umur 70 - 80 hari dan rata-rata bobot awal $1736 \pm 50 \mathrm{~g}(\mathrm{CV}=2,90 \%)$. Sebanyak 24 ekor (15 jantan dan 9 betina) dibagi secara acak ke dalam 3 perlakuan, masing-masing perlakuan terdapat 8 ulangan. Perlakuan yang diterapkan yaitu $\mathrm{T} 1=$ ransum basal, $\mathrm{T} 2=$ penyertaan Sargassum sp. 4\% pada ransum basal yang, T3 = penyertaan Sargassum sp. 8\% pada ransum basal.

Sargassum sp. diperoleh dari pantai Bandengan Kabupaten Jepara. Sargassum sp. kemudian dicuci bersih dan dijemur dibawah sinar matahari sampai kering. Setelah kering kemudian digiling dengan mesin grinder selanjutnya dikemas dan disimpan di dalam karung pada suhu ruang sampai digunakan untuk menyusun ransum.
Ransum basal yang digunakan adalah pakan komplit yang tersusun dari jagung kuning, pollard, bungkil kedelai, wheat bran, bekatul, kulit kopi, bungkil kelapa, molases, mineral dan garam. Ransum diformulasikan sedemikian rupa dengan kandungan protein kasar (PK) 15\% sesuai untuk kebutuhan kelinci pada masa pertumbuhan menurut Cheeke [9]. Kandungan PK ransum antar perlakuan tidak diformulasikan dalam kondisi iso protein karena tujuan penelitian ini adalah untuk mengevaluasi penyertaan Sargassum sp. pada ransum dengan level yang berbeda terhadap kandungan nutrien dan profil asam lemak karkas serta produksi limbah pada ternak kelinci. Ransum tersebut kemudian dibuat pelet dengan diameter pelet $0,5 \mathrm{~cm}$ dan panjang pelet $1-2 \mathrm{~cm}$. Pelet basah kemudian dijemur di bawah sinar matahari selama kurang lebih 3 jam. Komposisi dan kandungan nutrisi bahan pakan yang digunakan ditampilkan pada Tabel 1 . Kandungan nutrien kangkung dan rumput laut dapat dilihat pada Tabel 2.

\section{Pemeliharaan Kelinci}

Selama penelitian kelinci ditempatkan pada kandang individu dengan ukuran lebar $40 \mathrm{~cm}$, panjang $60 \mathrm{~cm}$ dan tinggi $40 \mathrm{~cm}$. Lantai kandang terbuat dari bilah bambu, dinding dan bagian atas kandang terbuat dari kawat ram ukuran $1 \times 1 \mathrm{~cm}$. Kandang dilengkapi tempat pakan yang terbuat dari gerabah dan nipple otomatis untuk tempat minum kelinci.

Tahap pemeliharaan kelinci terdiri dari dua tahap yaitu tahap pendahuluan dan tahap perlakuan. Tahap pendahuluan dilaksanakan selama 10 hari yang bertujuan untuk menghilangkan efek dari pakan yang diberikan sebelumnya, membiasakan ternak untuk diberi pakan perlakuan dan lingkungan kandang. Tahap pendahuluan dilakukan dengan cara memisahkan ternak sesuai dengan perlakuan dan ulangan dimana setiap kandang terdiri dari 1 ekor ternak, kemudian memberi pakan pelet sebanyak $130 \mathrm{~g}$ per ekor per hari yang diberikan dua kali setiap pagi dan sore hari, kangkung $10 \mathrm{~g}$ per ekor per hari setiap sore hari serta air minum secara ad libitum.

Tahap perlakuan dilaksanakan selama 12 minggu. Pada tahap ini perlakuan yang 
Tabel 1. Komposisi dan kandungan nutrien ransum penelitian

\begin{tabular}{|c|c|c|c|}
\hline \multirow{2}{*}{ Bahan Pakan } & T1 & $\mathrm{T} 2$ & $\mathrm{~T} 3$ \\
\hline & \multicolumn{3}{|c|}{ (\%) } \\
\hline Jagung kuning & 8,00 & 7,70 & 7,40 \\
\hline Pollard & 13,00 & 12,50 & 12,00 \\
\hline Bungkil kedelai & 9,00 & 8,60 & 8,30 \\
\hline Wheat bran & 38,00 & 36,50 & 35,00 \\
\hline Bekatul & 13,00 & 12,50 & 12,00 \\
\hline Kulit kopi & 8,00 & 7,70 & 7,40 \\
\hline Bungkil kelapa & 10,00 & 9,60 & 9,20 \\
\hline Molases & 0,20 & 0,20 & 0,20 \\
\hline Mineral & 0,40 & 0,40 & 0,40 \\
\hline Garam & 0,40 & 0,40 & 0,40 \\
\hline Rumput laut & - & 4,00 & 8,00 \\
\hline Total & 100,00 & 100,00 & 100,00 \\
\hline \multicolumn{4}{|l|}{ Kandungan } \\
\hline PK (\%) & 15,17 & 14,75 & 14,93 \\
\hline LK (\%) & 4,44 & 4,48 & 5,10 \\
\hline SK (\%) & 15,24 & 17,49 & 17,70 \\
\hline Abu (\%) & 6,06 & 6,66 & 7,64 \\
\hline $\mathrm{DE}(\mathrm{kcal} / \mathrm{kg})$ & 2950,73 & 2859,99 & 2824,44 \\
\hline
\end{tabular}

Keterangan : T1: ransum basal, T2: penyertaan Sargassum sp. 4\% pada ransum basal yang, T3: penyertaan Sargassum sp. $8 \%$ pada ransum basal

Tabel 2. Kandungan nutrien rumput laut dan kangkung

\begin{tabular}{ccc}
\hline Kandungan nutrien $(\%$ BK) & Sargassum sp. & Kangkung \\
\hline PK & 7,73 & 26,59 \\
LK & 2,02 & 4,29 \\
SK & 24,54 & 47,66 \\
ABU & 23,61 & 15,09 \\
\hline
\end{tabular}

diberikan pada ternak kelinci juga sama hanya pada tahap ini setiap pagi hari dilakukan penimbangan dan mengumpulkan sisa pakan sesuai perlakuan. Sisa pakan di homogenisasi dan dianalisis kadar bahan kering (BK) setiap minggu. Penimbangan ternak dilakukan setiap satu minggu sekali selama 12 minggu untuk mengetahui perkembangan bobot badan.

\section{Variabel Penelitian}

Diakhir penelitian (akhir minggu ke 12) sebanyak empat ekor kelinci jantan dari setiap perlakuan diambil secara acak dan disembelih. Kelinci ditimbang untuk mengetahui bobot sebelum puasa, kemudian kelinci dipuasakan selama 12 jam dan ditimbang kembali untuk mengetahui bobot potong. Penyembelihan dilakukan dengan cara memotong vena jugularis, arteri carotis dan oesophagus.

Kelinci yang sudah disembelih dikuliti, kemudian dilakukan pengeluaran organ viscera, pemotongan ekor, kaki, pemisahan kepala dan penimbangan karkas panas. Karkas yang telah ditimbang kemudian dimasukkan ke dalam ruang pelayuan selama 8 jam pada suhu $16^{\circ} \mathrm{C}$ dan ditimbang untuk mengetahui bobot karkas dingin. Hasil penimbangan tersebut kemudian dikonversikan ke dalam bobot potong.

Kandungan nutrien dan profil asam lemak daging diamati pada otot Longisimus dorsi (LD). Sampel otot LD diperoleh dari penguraian karkas setelah pelayuan. Sampel kemudian dibungkus dengan aluminium foil dan disimpan di freezer sampai dilakukan analisis. Pengamatan produksi feses dan urine 
dilakukan pada tahap total koleksi yaitu pada minggu ke 11. Feses ditampung dengan menggunakan nampan yang terbuat dari galvallum yang diletakkan disetiap kandang individu. Nampan dibuat sedemikian rupa sehingga posisinya miring dan pada ujung tersebut diberi lubang kecil sehingga urine akan mengalir terpisah dari feses. Urine ditampung dengan menggunakan botol plastik.

\section{Analisis Sampel}

Kandungan air daging dianalisis dengan metode pemanasan pada suhu $105^{\circ} \mathrm{C}$ selama 6 jam, kadar abu daging dianalisis dengan pemanasan sampel dari pengukuran kadar air pada suhu $550^{\circ} \mathrm{C}$ selama 6 jam, kandungan protein kasar (PK) daging dianalisis dengan metode kjeldahl, lemak kasar (LK) dianalisis dengan extraksi soxhlet [10]. Sampel untuk analisis kandungan PK daging adalah sebanyak kurang lebih 0,5 g sampel, setelah ditambahkan reagen dilanjutkan dengan proses destruksi, destilasi dan titrasi. Sampel yang dibutuhkan untuk analisis LK sebanyak kurang lebih 0,7-1 g. Sampel dibungkus dengang kertas saring halus, dioven pada suhu $105^{\circ} \mathrm{C}$ selama kurang lebih 7 jam, dilanjutkan dengan proses ekstraksi selama kurang lebih 4 jam. Kemudian sampel dianginkan anginkan pada suhu ruang selama kurang lebih 30 menit dan dilanjutkan dengan proses pengovenan pada suhu $105^{\circ} \mathrm{C}$ selama kurang lebih 2 jam. Berkurangnya berat sampel sebelum dioven dan setelah diektraksi dan setelah dioven merupakan berat LK sampel. Profil asam lemak dianalisis dengan menggunakan Gas Chromatography (Agilent Technologies 7890B Shimadzhu GC-2010 Plus). Kuantifikasi asam lemak daging dilakukan dengan normalisasi dan transformasi area persentase menjadi mg per $100 \mathrm{~g}$ porsi yang dapat dikonsumsi menggunakan faktor konversi lemak [11].

\section{Analisis Data}

Data hasil pengamatan dari setiap variabel yang diamati kemudian ditabulasi dan dianalisis variansi secara manual pada taraf $5 \%$ sesuai dengan Gomez dan Gomez [12].

\section{HASIL}

Rerata kandungan nutrien otot LD, persentase karkas dan produksi karkas kelinci NZW yang diberi pakan dengan penyertaan Sargassum sp. pada level yang berbeda dapat dilihat pada Tabel 3. Kadar air daging dari semua perlakuan pada rentang $72,46 \%$ $73,04 \%$, sementara itu kadar protein daging berkisar 20,48\%-21,02\%, sedangkan kadar lemak daging berkisar 1,27\%-2,97\%.

Profil asam lemak otot LD hasil penelitian dari ketiga perlakuan disajikan pada Tabel 4. Total konsentrasi asam lemak jenuh otot LD kelinci NZW pada perlakuan T1 lebih rendah dibanding total konsentrasi asam lemak jenuh otot LD pada perlakuan T2 dan T3. Kandungan asam lemak jenuh dari semua perlakuan berada pada rentang $32,67 \%-35,95 \%$, sedangkan untuk konsentrasi asam jenuh tunggal berkisar $37,33 \%-40,55 \%$ dan asam lemak jenuh ganda berkisar $23,94 \%$ $24,42 \%$.

Pengaruh penyertaan bahan pakan dengan Sargassum sp. dalam ransum terhadap produksi limbah disajikan pada Tabel 5. Rerata produksi limbah cair pada penelitian

Tabel 3. Kandungan nutrien otot LD dan produksi karkas kelinci

\begin{tabular}{lcccc}
\hline \multirow{2}{*}{\multicolumn{1}{c}{ Parameter }} & \multicolumn{4}{c}{ Perlakuan } \\
\cline { 2 - 5 } & $\mathrm{T} 1$ & $\mathrm{~T} 2$ & $\mathrm{~T} 3$ & P-Value \\
\hline Kadar air (\%) & $72,46 \pm 1,68$ & $73,04 \pm 0,71$ & $72,84 \pm 1,13$ & 0,798 \\
Kadar Abu (\%) & $2,28 \pm 0.84$ & $2,83 \pm 0,80$ & $2,43 \pm 0,62$ & 0,589 \\
Kadar Protein (\%) & $20,33 \pm 0.61$ & $21,02 \pm 0,63$ & $20,48 \pm 1,06$ & 0,459 \\
Kadar Lemak (\%) & $2,97 \pm 0,44^{\mathrm{a}}$ & $1,27 \pm 0,44^{\mathrm{b}}$ & $2,92 \pm 0,88^{\mathrm{a}}$ & 0,005 \\
Persentase Karkas (\%) & $55,23 \pm 1,62$ & $56,04 \pm 1,15$ & $55,18 \pm 1,81$ & 0,688 \\
Bobot Karkas Panas (g) & $1324,25 \pm 208,27$ & $1426,25 \pm 96,98$ & $1212,75 \pm 47,69$ & 0,138 \\
Bobot Karkas Dingin (g) & $1278,00 \pm 306,45$ & $1313,50 \pm 102,89$ & $1109,75 \pm 82,38$ & 0,325 \\
\hline
\end{tabular}

Keterangan : a,b Superkrip yang berbeda pada baris yang sama menunjukkan perbedaan nyata $(\mathrm{P}<0,05)$ 
Tabel 4. Profil asam lemak otot LD kelinci*

\begin{tabular}{|c|c|c|c|}
\hline \multirow{2}{*}{ Jenis Asam Lemak } & $\mathrm{T} 1$ & $\mathrm{~T} 2$ & T3 \\
\hline & \multicolumn{3}{|c|}{ (\% relatif) } \\
\hline \multicolumn{4}{|l|}{ Asam lemak jenuh (Saturated fatty acid/SFA) } \\
\hline Asam laurat, C12:0 & 2,00 & 2,44 & 2,64 \\
\hline Asam tridekanoat, C13:0 & - & 0,15 & - \\
\hline Asam miristat, C14:0 & 4,94 & 5,46 & 5,82 \\
\hline Asam pentadekanoat, C15:0 & 0,43 & 0,42 & 0,45 \\
\hline Asam palmitat, C16:0 & 24,70 & 26,31 & 26,51 \\
\hline Asam heptadekanoat, C17:0 & 0,46 & 0,51 & 0,53 \\
\hline Asam dokosanoat, C22:0 & 0,14 & 0,10 & - \\
\hline Total & 32,67 & 35,39 & 35,95 \\
\hline \multicolumn{4}{|c|}{ Asam lemak tidak jenuh tunggal (Monounsaturated fatty acid/MUFA) } \\
\hline Asam Cis 10-pentadekanoat, C15:1 & - & 0,11 & 0,15 \\
\hline Asam palmitoleat, C16:1 & 1,14 & 0,91 & 0,91 \\
\hline Asam miristoleat, C14:1 & - & 0,15 & 0,13 \\
\hline Asam cis 10-heptadekanoat, C17:1 & 0,13 & 0,11 & 0,10 \\
\hline Asam oleat, C18:1 & 27,97 & 27,28 & 26,61 \\
\hline Asam elaidat, C18:1 & 7,67 & 6,75 & 7,22 \\
\hline Asam cis 11-eicosanoat, C20:1 & 0,98 & 1,15 & 1,20 \\
\hline Asam erukat, C22:1 & 1,91 & 1,00 & 1,01 \\
\hline Asam nervonat, C24:1 & 0,48 & 0,27 & - \\
\hline Total & 40,55 & 37,73 & 37,33 \\
\hline \multicolumn{4}{|c|}{ Asam lemak jenuh ganda (Polyunsaturated fatty acid/PUFA) } \\
\hline Asam linolelaidat, C18:2 & - & - & 0,19 \\
\hline Asam linoleat, C18:2 & 23,39 & 23,73 & 23,13 \\
\hline Asam $\gamma$-linolenat, C18:3 & 0,29 & 0,17 & 0,13 \\
\hline Asam linolenat, C18:3 & 0,27 & 0,29 & 0,24 \\
\hline Asam cis 11,14-eikosadienoat, C20:2 & 0,14 & 0,13 & 0,15 \\
\hline Asam cis 4,7,10,13,16,19-dokosahexanoat, C22:6 & 0,17 & 0,10 & 0,10 \\
\hline Total & 24,26 & 24,42 & 23,94 \\
\hline Total asam lemak & 97,19 & 97,57 & 97,60 \\
\hline
\end{tabular}

Keterangan : *Tidak dilakukan analisis statistik

Tabel 5. Produksi limbah kelinci

\begin{tabular}{lcccc}
\hline \multirow{2}{*}{ Poduksi Limbah } & \multicolumn{4}{c}{ Perlakuan } \\
\cline { 2 - 5 } & $\mathrm{T} 1$ & $\mathrm{~T} 2$ & $\mathrm{~T} 3$ & P-Value \\
\hline Produksi limbah cair (ml/ekor/hari) & $741,79 \pm 582,92$ & $658,18 \pm 442,93$ & $1024,56 \pm 1204,56$ & 0,646 \\
Produksi feses segar (g/ekor/hari) & 244,34 & 334,48 & 266,50 & - \\
Produksi BK feses (g BK/ekor/hari) & $32,66 \pm 15,29$ & $37,34 \pm 8,90$ & $29,90 \pm 5,51$ & 0,389 \\
\hline
\end{tabular}

Keterangan : ${ }^{*}$ Tidak dilakukan analisis statistik

ini yaitu 741,79; 669,43 dan 1024,98 ml/ekor/ hari untuk perlakuan T1, T2 dan T3.

\section{PEMBAHASAN}

Penelitian Al-Dobaib [13] pada bangsa kelinci Spanyol V dengan pakan berkadar PK 20\% mendapatkan nilai kadar air daging kelinci sebesar 70,7\%; PK daging 19,71\%; LK daging 8,38\% dan kadar abu 1,09\%.
Penelitian Pla et al. [14] dari daging Longisimus dorsi yang beredar dipasar modern di Spanyol mendapatkan bahwa kandungan protein kasar 22,1; kadar lemak berkisar antara 1,2\%. dan kadar air 75,6\%. Dengan demikian kadar air otot LD pada penelitian ini masih dalam kisaran kadar air daging kelinci menurut Al-Dobaib [13].

Persentase karkas kelinci pada penelitian ini adalah 55,23\%; 56,04\% dan 55,18\% untuk 
perlakuan T1, T2 dan T3. Nilai tersebut masih dalam kisaran yang normal untuk karkas kelinci. Dalle Zotte [15] menyatakan bahwa persentase karkas kelinci berkisar antara $55-60 \%$, sedangkan Milisits et al. [16] menyatakan bahwa persentase karkas kelinci berkisar antara 55-61\%.

Tidak berbedanya $(\mathrm{P}>0,05)$ kandungan air, abu dan protein otot LD kelinci NZW pada penelitian ini disebabkan relatif samanya umur kelinci pada saat pemotongan. Selain hal tersebut, penyertaan Sargassum sp. sampai pada level $8 \%$ pada ransum di penelitian ini tidak menyebabkan perubahan kualitas ransum secara mendasar. Hal ini diduga berperan serta menyebabkan tidak berbedanya $(\mathrm{P}>0,05)$ pengaruh perlakuan pada kandungan air, abu dan protein otot LD kelinci NZW. Grashorn et al. [17] menyatakan bahwa pada bangsa kelinci NZW yang disembelih pada umur dewasa (112 hari) kualitas daging tidak lagi dipengaruhi oleh bobot potong (2,8 VS 3,3 kg), sedangkan pada penelitian ini kelinci disembelih kurang lebih pada umur 180 hari. Adapun kadar lemak otot LD pada perlakuan T1 lebih tinggi $(\mathrm{P}<0,05)$ dibanding kadar lemak otot LD dari perlakuan $\mathrm{T} 2$, namun tidak berbeda nyata $(P>0,05)$ dengan T3. Hal ini disebabkan oleh lebih tingginya kandungan energi ransum (Tabel 1) perlakuan T1 dibanding dengan perlakuan yang lainnya. Adapun kadar lemak otot LD dari perlakuan T1 yang tidak berbeda nyata $(\mathrm{P}>0,05)$ dengan kadar lemak otot LD dari perlakuan T3 bisa dijelaskan secara ilmiah dan penulis belum menemukan pustaka yang dapat digunakan untuk menjelaskan fenomena tersebut. Dale Zotte [15] menyatakan bahwa pemberian pakan dengan kandungan energi tinggi setelah periode penyapihan, penggemukan sampai saat dipotong tidak berpengaruh pada pertumbuhan, konsumsi pakan dan produksi karkas kelinci tetapi berpengaruh pada menurunnya konversi pakan dan meningkatnya kandungan lemak daging. Kandungan lemak otot LD pada penelitian masih dalam kisaran normal kandungan lemak otot LD kelinci seperti yang disampaikan oleh Dale Zotte [15] bahwa kandungan lemak otot LD pada kelinci berkisar antara $1-2 \%$.
Hasil analisis statistik memperlihatkan bahwa pengaruh penyertaan Sargassum sp. pada ransum kelinci NZW tidak nyata $(\mathrm{P}>0,05)$ terhadap persentase karkas, bobot karkas panas dan bobot karkas dingin. Tidak berbedanya persentase karkas ini disebabkan tidak berbedanya bobot potong kelinci antar perlakuan. Bobot potong kelinci pada penelitian ini adalah $2395 \mathrm{~g}, 2545 \mathrm{~g}$ dan $2199 \mathrm{~g}$ untuk perlakuan T1, T2 dan T3. Tidak berbedanya bobot potong kelinci pada penelitian ini dapat disebabkan oleh kemampuan kelinci yang relatif sama untuk dapat memanfaatkan kandungan nutrient pada ransum baik pada perlakuan kontrol maupun pada ransum perlakuan.

Dalle Zote [15] menyatakan bahwa kualitas daging dan karkas kelinci termasuk persentase karkas antara lain dipengaruhi oleh genetik, umur, bobot potong, temperature lingkungan, iklim, manajemen pemeliharaan terutama perkandangan, pakan, kondisi sebelum pemotongan, metode pemingsanan sebelum pemotongan dan lain sebagainya.

Penggunaan Sargassum sp. pada pakan menyebabkan kenaikan total konsentrasi asam lemak jenuh dan menurunkan konsentrasi relatif dari asam lemak tak jenuh terutama asam lemak tak jenuh tunggal (Tabel 4). Hal ini disebabkan terjadinya kenaikan persentase kandungan asam lemak palmitat pada otot LD dari perlakuan T2 dan T3. Kenaikan kandungan asam lemak palmitat otot LD kelinci NZW ini tidak terlepas dari tingginya kandungan asam lemak palmitat pada Sargassum sp. Hasil penelitian Matanjun et al. [8] menyatakan bahwa konsentrasi asam lemak palmitat pada Sargassum polycystum mencapai 37,97\% jauh lebih tinggi dibanding kandungan asam lemak palmitat pada rumput laut Eucheuma cottonii $(15,10 \%)$ dan Caulerpa lentillifera $(33,78 \%)$.

Diantara asam tidak lemak jenuh yang konsentrasinya cukup tinggi pada daging kelinci dari penelitian ini (dari perlakuan T1, T2 dan T3) diantaranya adalah asam lemak elaidat $(6,75-7,67 \%)$; asam lemak oleat $(26,61$ $27,97 \%)$ dan asam lemak linoleat (23,13$23,73 \%$ ). Konsentrasi asam lemak linoleat yang sangat tinggi pada daging kelinci 
merupakan kelebihan dari daging kelinci dibanding daging dari ternak yang lain mengingat asam lemak linoleat merupakan salah satu jenis asam lemak essensial. Hasil penelitian Sugiharto et al. [18] menunjukkan bahwa kandungan asam lemak linoleat pada daging dada ayam broiler dengan pakan yang mengandung $20 \%$ campuran onggok dan tepung daun kelor yang difermentasi dan $0,1 \%$ probiotik Bacillus subtilis adalah sebesar21,4\%.

Hernàndez dan Dalle Zotte [19] menyatakan bahwa konsentrasi saturated fatty acids (SFA) pada daging kelinci sebesar 38,9\%; monounsaturated fatty acids (MUFA) sebesar $28,0 \%$ dan poly unsaturated fatty acids (PUFA) sebesar 32,5\% dengan demikian kandungan asam lemak otot LD daging kelinci pada penelitian ini masih dalam kisaran kandungan asam lemak daging kelinci menurut hasil penelitian terdahulu. Kandungan PUFA daging kelinci jauh lebih tinggi dibanding kandungan PUFA pada daging sapi dan daging babi. Konsentrasi PUFA daging sapi sebesar $8,79 \%$ sedangkan konsentrasi PUFA daging babi sebesar $13,8 \%$ [20]. Tingginya konsentrasi PUFA daging kelinci tentunya merupakan nilai lebih karena konsumsi SFA akan meningkatkan low density lipoprotein (LDL) kolesterol sedangkan konsumsi PUFA akan dapat menurunkan level konsentrasi LDL kolesterol [21].

Penyertaan Sargassum sp. pada ransum sampai pada taraf $8 \%$ tidak memberikan pengaruh yang nyata $(\mathrm{P}<0,05)$ terhadap produksi bahan kering (BK) feses. Hal ini disebabkan tidak berbedanya konsumsi dan kecernaan BK ransum dari masingmasing perlakuan (data tidak ditampilkan). Penelitian Hoover dan Heitmann [22] mendapatkan hasil bahwa kandungan serat kasar yang tinggi pada ransum kelinci menyebabkan penurunan yang signifikan terhadap pertambahan bobot badan, kecernaan BK dan energi dan secara signifikan menyebabkan peningkatan volume feces per kilogram bobot badan. Sementara itu Carabaño et al. [23] mendapatkan produksi feces kelinci NZW pada masa pertumbuhan berkisar antara 14,98-29,59 g DM/hari. Lebih tingginya produksi feses kelinci pada penelitian ini disebabkan oleh perbedaan umur pada saat koleksi feses. Pada penelitian ini koleksi feses dilakukan pada saat akhir penelitian pada saat umur kelinci sekitar 180 hari dimana pada saat tersebut kelinci sudah dewasa sedangkan pada penelitian Carabaño et al. [23], koleksi feses dilakukan pada kelinci NZW yang masih dalam masa pertumbuhan.

Penggunaan Sargassum sp. pada ransum sampai pada taraf $8 \%$ pada penelitian ini tidak memberikan pengaruh yang nyata $(P>0,05)$ terhadap produksi limbah cair, hal ini disebabkan tidak berbedanya konsumsi BK ditiap perlakuan. Dengan tidak terdapatnya perbedaan konsumsi BK ransum tersebut menyebabkan konsumsi air minum juga relatif sama antar perlakuan sehingga produksi urine juga tidak berbeda. Hal lain yang menyebabkan tidak berbedanya pengaruh perlakuan terhadap produksi limbah cair karena tingginya variasi produksi limbah cair antar ternak dalam penelitian ini. Møller et al. [24] menyatakan bahwa kuantitas dan kualitas slurry dari satu peternakan sapi ke peternakan yang lain dapat sangat berbeda tergantung dari banyak faktor seperti terbuangnya sisa pakan ke limbah, terbuangnya alas tidur ternak ke limbah, terbuangnya air minum ke limbah, sistem perkandangan dan sistem pemeliharaan.

\section{KESIMPULAN}

Penggunaan Sargassum sp. pada ransum kelinci sampai pada taraf $8 \%$ tidak berdampak pada produksi karkas, kandungan protein, abu dan air daging, serta produksi limbah yang dihasilkan. Bahkan penyertaan Sargassum sp. pada ransum pada taraf $4 \%$ mampu menurunkan kandungan lemak daging kelinci. Dengan demikian ditinjau dari parameter pengamatan di atas, Sargassum sp. dapat digunakan untuk mensubstitusi bahan pakan kelinci sampai dengan taraf $8 \%$.

\section{KONFLIK KEPENTINGAN}

Para penulis menyatakan tidak terdapat konflik kepentingan dengan pihak manapun terkait dengan materi yang ditulis pada naskah publikasi ini. 


\section{REFERENSI}

1. Hernàndez, O.J.A., and R. M. S. Lozano. 2001. Effect of breed and sex on rabbit carcass yield and meat quality. World Rabbit Sci. 9(2):51-56. DOI: https://doi.org/ 10.4995/wrs.2001.445.

2. Mailafia, S., Onakpa, M.M., and Owoleke O.E. 2010. Problems and prospects of Rabbit production in nigeria - A Review. Bayero J. Pure Appl. Sci., 3(2): 20-25.

3. Dalle Zotte, A. 2002. Perception of rabbit meat quality and major factors influencing the rabbit carcass and meat quality. Livest. Prod. Sci. 75:11-32. https://doi.org/10.1016/ S0301-6226(01)00308-6

4. Akande, K.E. 2015. Dietarry effect of increasing level of pigeon pea meal on rabbit performance. J. Agric. Sci. 7(7):156162. Doi:10.5539/jas.v7n7p156.

5. Hambakodu, M., E. Pangestu, dan J. Achmadi. 2019. Substitusi rumput gajah dengan rumput laut coklat (Sargassum polycystum) terhadap produk metabolisme rumen dan kecernaan nutrien secara in vitro. Jurnal Ilmu-Ilmu Peternakan 29(1):37-45. DOI: https://doi.org/10.21776/ ub.jiip.2019.029.01.05

6. Budhiyanti, S.A., S. Raharjo, D. W. Marseno, and I. Y. B. Lelana. 2012. Antioxidant activity of brown algae Sargassum species extract from the coastline of Java island. American J. Ag. Biol. Sci. 7(3):337-346. doi:10.3844/ajabssp. 2012.337.346.

7. Marín, A., M. Casas-Valdez, S. Carrillo, H. Hernández, A. Monroy, L. Sanginés, and F. Pérez-Gil. 2009. The marine algae Sargassum spp. (Sargassaceae) as feed for sheep in tropical and subtropical regions. Rev. Biol. Trop. 57 (4):1271-1281.

8. Matanjun, P., S. Mohamed, N. M. Mustapha, and K. Muhammad. 2010. Nutrient content of tropical edible seaweeds, Eucheuma cottonii, Caulerpa lentillifera and Sargassum polycystum. J, Appl. Phycol. 21:75-80. https://doi.org/ 10.1007/s10811-008-9326-4.

9. Cheeke, P.R. 1987. Rabbit feeding and nutrition. Academis press Inc, Orlando, San Diego, New York, Austin, Boston, London, Sydney, Tokyo, Toronto.
10. AOAC. 1990. Official methods of analysis (13 $3^{\text {th }}$ Ed). Association of official analytical chemist Inc. Washington Dc.

11. Holland, B., A.A. Welch, I.D. Unwin, D.H. Buss, A.A. Paul, and D.A.T. Southgate. 1998. The composition of foods. London: The Royal Society of Chemistry.

12. Gomez, K.A., A.A. Gomez. 2007. Prosedur statistik untuk penelitian pertanian. Diterjemahkan oleh Sjamsuddin E and Baharsjah JS. UI Press, Jakarta.

13. Al-Dobaib, S.N. 2010. Effect of diets on growth, digestibility, carcass and meat quality characteristics of four rabbit breeds. Saudi J. Biol. Sci. 17:83-93. https://doi.org/ 10.1016/j.sjbs.2009.12.012.

14. Pla M, M. Pascual, and B. Ariño. 2014. Protein, fat and moisture content of retail cuts of rabbit meat evaluated with the nirs methodology. World Rabbit Sci. 12(3):149156.

15. Dalle Zotte, A. 2000. Main factors influencing the rabbit carcass and meat quality. In: Proceedings of the $7^{\text {th }}$ world rabbit congress, Valencia Spanyol, 4-7 July. pp. 10-15.

16. Milisits G., Romvári R., Szendro Zs., Masoero G., Bergoglio G. 2000. The effect of age and weight on slaughter traits and meat composition of pannon white growing rabbits. In: Proceedings of the $7^{\text {th }}$ world rabbit congress, Valencia Spanyol, 47 July. pp. 629-634.

17. Grashorn, M.A., J. Zimmermann, and W. Bessei. 1996. Meat quality features of light and heavy types of New Zealand White rabbits. In: Proceedings of the $6^{\text {th }}$ World Rabbit Congress, Toulouse, France, 9-12 July. pp. 173-175.

18. Sugiharto, S., E. Widiastuti, I. Isroli, T. Yudiarti, T. A. Sartono and H.I. Wahyuni. 2019. Breast meat characteristics of broilers fed fermented mixture of cassava pulp and Moringa oleifera leaf meal. J. Indonesian Trop. Anim. Agric. 45(2):103-114. DOI: 10.14710/jitaa.45.2.103114.

19. Hernàndez, P., A., and Dalle Zotte. 2010. Influence of diet on rabbit meat quality. In: Nutrition of the rabbit. Edited by C. de Blas, Univesidad Poletenica, Madrid. pp 163-178. 
20. Dalle Zotte, A., and Z. Szendrő. 2011. The role of rabbit meat as functional food. Meat Sci. 88:319-331. https://doi.org/ 10.1016/j.meatsci.2011.02.017

21. Whitney, E.N., R.S. Rolfes. 2002. Understanding nutrition (9 $9^{\text {th }}$ ed.). Belmont, CA: Wadsworth/Thomson Learning.

22. Hoover, W.H., and R. N. Heitmann. 1972. The Journal of Nutrition 102:375-379.

23. Carabaño M.J.R., F.G. Santomá, and J.C. de Blas. 1988. Effect of diet on composition of cecal contents and on excretion and composition of soft and hard feces of rabbits. J. Anim. Sci. 66:901-910. https:// doi.org/10.2527/jas1988.664901x

24. Møller, H.B., S.G. Sommer, and B.K. Ahring. 2004. Methane productivity of manure, straw and solid fraction of manure. Biomas Bioenergy. 26:485-495. https://doi.org/10.1016/j.biombioe.2003.08. 008. 